\title{
An Explanative Study On The Module For Supervising And Assessing Education Staff Performance At Principal Empowerment Training
}

\author{
Heri Supriyana \\ Institute for Development and Empowerment \\ of Principals and Supervisors.
}

\begin{abstract}
The result of 2015 principal competency test shows that most of principals have not sufficient principal competency so that they have not been able to carry out their main tasks and functions properly. Likewise, the most of principals who have been appointed as principals do not yet have a Certificate of principal training, so that the most of principals do not meet the requirements to become principals. Based on this problem the Ministry of Education and Culture conducts training for strengthening principals with certain modules. The Directorate General of Teachers and Educational Personnel has written a training module for strengthening principals. These modules include the supervision module and the performance assessment of the education staff written by the author. The module has not been tested for relevance, adequacy, consistency, and sequences. In order to obtain a module for supervision and the performance assessment of teaching staff that is ready to be used in education and training, this study was conducted. The purpose of this study was to determine the level of relevance, adequacy, consistency, and sequences of the supervision module and the assessment of the performance of the education staff in the training of strengthening principals. This research is an explanative research. The data collection method uses closed questionnaire and open questionnaire techniques. The results of this study are the relevance aspects of getting a score of 3.73 (good enough), the adequacy aspect of getting a score of 3.64 (good enough), the consistency aspect of getting a score of 3.74 (good enough), the aspect of sequencing getting a score of 3.86 (good enough). Besides that from the systematic aspect of writing the category of statement "quite systematic" has the largest percentage of $77.10 \%$, the aspect of appearance / graphic design of the category of statement "quite good" has the largest percentage of $74.23 \%$, on the aspect of content / content category of statement "enough complete and detailed "has the largest percentage of $\mathbf{7 8 . 5 8 \%}$. The conclusion of this research is that the supervision module and the performance assessment of the education staff in the sc principal strengthening training program are good enough to be used in the principal strengthening training because they are relevant, sufficient content, consistent enough and inter-material enough sequences.
\end{abstract}

Keywords: explanatory study; module; supervision; performance assessment; educational staff.

\section{CHAPTER I INTRODUCTION}

\section{Background}

The principal has main tasks which include; (a) managerial,(b) developing entrepreneurship and (c) supervision of teachers and educational staff (RI Government Regulation No. 19 of 2017 article 54 paragraph 1. Based on these basic tasks the principal has a function or role as manager and as supervisor The principal as a manager must be able to carry out the main tasks in the managerial field related to school management, so that all resources can be optimally provided and utilized to achieve school goals effectively and efficiently. 
The principal as a supervisor has the main task of supervising the implementation of the teachers and education staff that aims to ensure that teachers and staff work well and maintain the quality of the process and the results of the goals. In this task of supervision of teachers and educational staff, the activities of the principal include: (a) Planning the supervision program, (b) Carrying out the supervision program, and (c) Feed back on the supervision program. If the principal's job as a supervisor is carried out properly in accordance with the existing guidelines, all teachers and education staff / staff will work well because they receive monitoring and guidance in working. Teachers will be motivated in the improvement of learning.

In the Regulation of the Minister of National Education No. 13 of 2007 it is stated that there are five dimensions of competency that must be owned and controlled by the principal to be able to carry out the main tasks, functions, and responsibilities as the principal, these five competency dimensions include: (a) personality competence, (b) social competencies, (c) managerial competencies, (d) supervision competencies, and (e) entrepreneurial competencies. The five dimensions of competency can be mastered by the principal through activities that can improve the competency of the principal. These activities take the form of education and training or are often referred to as "training". Through the training above, it is expected that five competency dimensions (personality, social, managerial, supervision, entrepreneurship) can be mastered well by the principal.

In addition to the competencies that must be fulfilled by the principal, regulation must also be met. One form of regulations of a principal is the possession of a Certificate of Completion of Education and Training (STTPP) for the Principal (Permendikbud RI No.6 Year 2018 Article 10 paragraph 1).

The above expectations were not yet fully undertaken, based on field studies that many principals were not able to master the five dimensions of competency of principals so that they could not carry out their main tasks and functions properly. Likewise, most principals who have been appointed as principals do not yet have STTPP principals, so that the most of principals have not legally met the requirements to become principals.

The results of the Principal Competency Test conducted by the Ministry of Education and Culture in 2015 obtained an average of 3 competency principals is 56.37, for the managerial dimension 58.55, for the supervision dimension of learning 51.81, and for the entrepreneurship dimension of 58.75 . These results indicate that principals need more serious attention in increasing competence (Source: Principal Work Handbook; 2017).

To overcome the problems of legalization and competence as mentioned above the need for education and training to strengthen the principal comprtency. In this regard the government through the Minister of Education and Culture issued guidelines for the implementation of the Ministry of Education and Culture Regulation

No. 6 of 2018, explained the procedure for strengthening principals.

In training the strengthening of principals required factors supporting the success of the training. One of the factors supporting the success of education and training is the existence of modules used in training activities. In 2018 the Directorate General of Teachers and Education Personnel has compiled a Training Module for strengthening principals. There are a number of Modules used in the principal's strengthening training program including the supervision module and the performance assessment of the education staff written by the author. The 
modules are still needed further development so that in terms of relevance, adequacy, consistency, and order of presentation included in both categories.

In order to get the description of the relevance, adequacy, consistency, and order of presentation of the supervision module and the performance assessment of the education staff that has been written by the author, a descriptive study was carried out entitled "An Explanative Study On The Module For Supervising And Assessing Education Staff Performance At Principal Empowerment Training"

\section{Identification of Problems}

1. Most of the principals do not have a letter of completion of education and training / STTPP so that legalization does not meet the requirements.

2. Most principals cannot carry out their main tasks as principals because they have not mastered the competency dimensions of principals in accordance with the mandate of Ministry of Education Regulation No. 13/2007.

3. The relevance, adequacy, consistency, and order of presentation in the supervision module are not tested yet and either is the performance of educational staff.

\section{Problem Formulation}

To what extent are the relevance, adequacy, consistency, and order of presentation of the supervision and evaluation modules of the performance of the teaching staff in training for strengthening principals?

\section{Purpose}

To describe the relevance, adequacy, consistency, and sequence of presentation of the supervision module and the assessment of the performance of the education staff in the training of strengthening principals.

\section{Benefits}

To assist institutions related to education and training for principals in preparing teaching material for supervision and performance assessment of educational staff.

\section{Basic Theory Training Module \\ Understanding Modules}

According to Anwar (2010) learning modules are instructional materials that are written in a systematic and interesting way that includes the content of the material, methods and evaluations that can be used independently to achieve the expected competencies. Meanwhile according to W.S. Winkel (2009: 342-343) module is any learning material that is expected to be absorbed or transferred to learners. What is meant by learners in this study are training participants.

Based on the description above, it can be concluded that the module is a set of material that is written systematically and is used by the teacher / instructor in carrying out teaching and learning activities in class. In this study, what is meant by modules is a set of materials that are written systematically and used by instructors / trainers in carrying out learning activities in the training of strengthening principals. 


\section{Module Characteristics}

Learning module is one of the learning materials that can be utilized by learners / training participants independently. A good module must be written systematically, interestingly, and clearly. Modules can be used anytime and anywhere according to the needs of learners/training participants. Anwar (2010) states that the characteristics of the learning modules are as follows: (1) Self -instructional; learners are able to learn themselves, not dependent on other materials, (2) Self- contained; all learning materials from one competency unit studies contained in one whole module, (3) Stand alone; developed modules are not dependent on other media or do not have to be used together with other media, (4) Adaptive; modules should have a high adaptive power to the development of science and technology, (5) User friendly; the module should also meet the familiar rules of friendly / familiar with the wearer, (6) Consistency; consistent use of fonts, spaces, and layout.

\section{Concepts of Supervision and Assessment of Educational Performance Definition of Educational Staff Supervision}

Supervision is activity carried out by the principal in order to assist teachers and other educational staff in order to improve the quality and effectiveness of the administration of education and learning. The definition of supervision as stated by Ametembun in the Directorate of Education Personnel of the Ministry of National Education (2008) that based on the terminology, supervision consists of two words super + vision: Super $=$ over, more, Vision $=$ see, view, supervise. The meaning of a supervisor is someone who has a position more than the supervisee, his task is to see, observe or supervise the supervisee. Oliva (1984) stated that supervision of instruction is what school personal do with adults and things to maintain or change the school operation in ways that directly influence the teaching process employed to promote pupil learning Supervision carried out by the principal is to provide services to teachers and education staff in carrying out the job effectively and efficiently. Supervision has two aspects, namely managerial supervision and academic supervision. Managerial supervision (education staff) focuses on monitoring, coaching, and mentoring on aspects of school management and administration that provides the implementation of learning. While academic supervision focuses on monitoring, coaching, and guiding teachers on academic activities, in the form of learning both inside and outside the classroom. Educational staff are members of the community who are devoted and appointed to support the implementation of education. (Law No. 20 of 2003 article 1, Chapter 1 General Provisions). Educational staff are staff in charge of planning and implementing administration, management, development, supervision, and technical services to support the education process in the education unit. (Law No. 20 of 2003, Article 39 (1). The types of education staff referred to in this learning material include: School Administration Staff /TAS (head of TAS, executive affairs, special service staff), Library staff ( Head of library, library staff), and laboratory staff (Head of laboratories, laboratory technicians, laboratory assistants) Supervision of Educational staff is supervision which is carried out by principals to educational staff related to the management and administration of education so that it will support the learning process at schools.

Based on the explanations above, in this study what is meant by the supervision of education staff is a series of activities which include; preparation, implementation and follow-up to help education staff develop their abilities in carrying out tasks to support and to manage the learning process

\section{Principles of Supervision of Educational Staff}

Implementation of the supervision of educational staff can run effectively if the principals can understand and master the principles of supervision of the staff. Among the principles that have a positive impact in carrying out managerial supervision are supervisors don't have 
authoritarian attitude, supervisors are able to create good human relations, supervision of educational staff is carried out continuously, supervision programs are integrated with other programs, supervision must be comprehensive, supervision must be constructive, supervision must be constructive, and supervision must be objective.

\section{Concept of Performance Assessment of Educational Staff Definition of Performance Educational Staff}

Assessment is the process of collecting, processing, analyzing and interpreting data as material for decision making. Each assessment activities focus to decision making. Educational staff are staff appointed to plan and carry out administration, management, development, supervision and technical services to support the educational process in the education unit (Article 39 of Law No. 20 of 2003). Performance evaluation of education staff is a process of collecting, processing, analyzing, and interpreting data that is actually carried out by education staff.

\section{Principles of Performance Assessment of Educational Staff}

Principles of performance assessment of educational staff are as follow: (1) Objectives; assessment is carried out in accordance with the actual conditions when the staff carry out their activites. To maintain the objectivity of assessment, the assessment process uses a check, recheck and cross-check approach. (2) Accountable; the process and results of the assessment must be accountable to the proponent given the task, as well as to the parties concerned with the performance appraisal. (3) Transparent; both the process and the results of the performance assessment can be known by staff and it can be used as career feedback and guidance. (4) Confidential; staff performance assessment is only for the persons being assessed. Therefore, instruments, records and assessment results are only known by the supervisor and the staff being assessed or other persons who are responsible to assesst the staff. (5) Valid; the task component measures what is to be measured. (6) Reliability; it is a high level of confidence if the process carried out provides the same results for staff whose performance is judged by anyone and at any time. (7) Practical; it is said to be practical if it can be done by anyone easily, with the same level of validity and reliability in all conditions without the need for additional requirements.

\section{Concept of Training for Strengthening Principals \\ Definition of Education and Training}

According to the State Administration Institute (2009: 3) understanding education and training is a learning process that is intended to change one's work competence so that he can perform better in his position. Based on Government Regulation Number 101/2000 what is meant by 'Training' is a learning process in order to improve the ability of Civil Servants. Learning is done by Civil Servants to improve their personality, knowledge and skills in accordance with the requirements of their job and job requirements as Civil Servants. In this study, the Civil Servants are teachers who are appointed as principals.

Based on the above understanding, it can be explained that training is a learning process in order to improve the personality, knowledge and skill of training participants in accordance with the requirements of their job and job requirements. What is meant by position and occupation in this case is the position of teacher who is assigned as a principal. Furthermore, in this study what is meant by training for strengthening principals is a learning process in order to improve the personality, knowledge, and skill of principals who have served in a certain period of time. 


\section{Aims and Targets of the Training}

The Purpose of Education and Training in Government Regulation No. 101 of 2000 it is stated that the Education and Training aims to; (1) increasing knowledge, expertise, skills, and attitude to be able to carry out professional duties based on the personality and ethics of civil servants in accordance with the needs, (2) creating prinsipal that is able to act as a reformer and of national unity person, and (3) strengthening attitude, spirit of service-oriented, and support, and community empowerment, (4) creating a same vision, mission, and dynamic mindset in carrying out the tasks of general government and development for the realization of good governance. While the training target is the realization of civil servants who have competencies that are in accordance with the requirements of their positions.

Based on the description above, the aims and objectives of the training in this study are (1) increasing knowledge, skills, and attitudes to be able to carry out their professional duties as principals based on personality and ethics in accordance with the needs of the school, (2) creating principals who are able to play a role as educational reformers in Indonesia, (3) strengthening the attitude and spirit of public service as principals oriented to service, guidance, and community empowerment, (4) creating a same vision, mission, and dynamic mindset in carrying out tasks as a principal for the realization of high educational quality. Whereas the target of the education and training program is the realization of school principals who have competencies in accordance with Minister of National Education Regulation No. 13 of 2007 concerning School / Madrasah Competency Standards which include (a) personality competence, (b) social competence, (c) managerial competence, (d) supervision competencies (e) entrepreneurial competencies.

\section{Strengthening Principal Training}

In the Permendikbud Implementation Guideline Number 6 of 2018 it is explained that education and training/ training for strengthening principals/ madrasas are activities providing theoretical and practical learning experiences aimed at fostering knowledge, attitudes, and skills on dimensions of personality competencies, managerial, entrepreneurship, supervision, and social.

\section{Principal Strengthening Training Model}

Education and training activities for strengthening principals / madrasas in the form of face-toface activities held in a minimum duration of 71 hours @ 45 minutes (Perdirjend: 2018). The training material covers general material, main material and supporting material. General materials include; 1) policy, 2) program orientation. main Materials: 1) development of managerial competencies, 2) development of supervisory competencies, 3) leadership (personality, social, and entrepreneurial competencies). Supporting material: 1) pre-test and post-test, 2) training evaluation, 3) follow-up plan. Pre-test and Post-test include knowledge of managerial competence and supervision. At the beginning of the training, a pre-test was conducted to find out the extent of participants' mastery of managerial and supervision material. While at the end of the training, a post-test was conducted to determine the absorption of training participants during the training activities for strengthening principals and also carried out training evaluations which included evaluations of the implementation, programs and trainers 


\section{Conceptual Framework}

Figure 1. Chart of Mindset

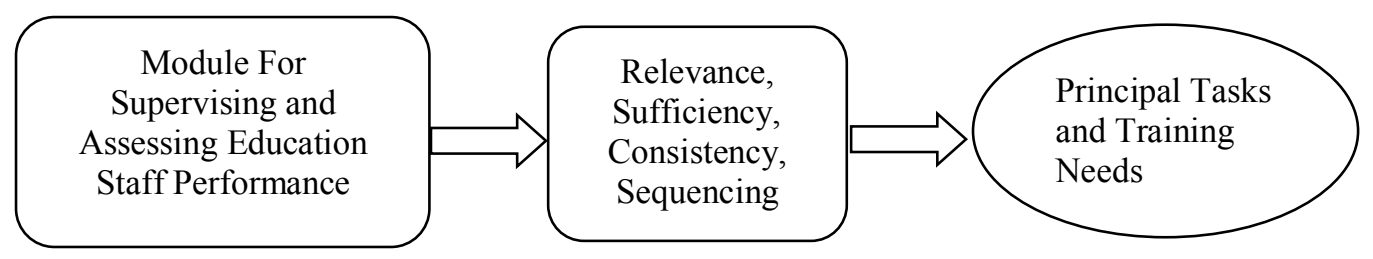

\section{Information :}

Teaching material for supervision and supervision of performance of education staff is further explored, conducting explanatory research to explain the level of relevance, adequacy, consistency, sequence of presentation of teaching material, so that the character of the supervision material and the performance assessment of education staff is in accordance with the training needs and needs of the principal in carrying out their tasks as supervisors and assessors of performance assessment.

\section{CHAPTER III \\ RESEARCH METHOD}

This research will use a descriptive research method with the following description:

\section{Research Design}

According to Moh Nazir (2005: 99) research design is all the processes required in the planning and implementation of research or operational research. The types of research designs according to Sell Tiz, e. All; quoted by Moh. Nazir (2005: 104) there are 3 types of research designs, namely: (1) Design for explorative and formulative studies, (2) Design for descriptive / explanatory studies, (3) Design for studies testing causal hypotheses. According to Moh. Nazir (2005: 105) explanatory research is research to find facts and interpretations. Furthermore Moh. Nazir (2005: 105) also explained that descriptive research studies include studies to describe some group or individual phenomena and also studies to determine the frequency of occurrence of a condition to minimize bias and maximize reality. A similar opinion was stated by Suharsimi Arikunto (2010: 309) that descriptive research is research to gather information about the status of an existing phenomenon according the reality when the study was conducted. The descriptive method is the most basic of the quantitative research.It involves describing of a particular sample of individual or other phenomena ((Gall, Gall \& Borg203: 288)

Based on these opinions, the purpose of the descriptive study research is to gather information or facts about the status of a phenomenon that existed at the time the study was conducted to obtain an appropriate interpretation.

\section{Research Subjects}

Suharsimi Arikunto (2010: 109) explains that research subjects are objects, things, or people where data are obtained that are related to the research variables and the issue. The research subjects in this study were participants in the training of principals strengthening. Participants in the training program for strengthening principals were principals who had been appointed before July 1, 2017. Thus the research subjects in the study were training participants for strengthening principals in Kebumen, Central Java Province, with a total of 35 training participants. 


\section{Research Population}

According to Moh. Nazir (2005: 225) population is a collection of individuals with predetermined quality qualities. Another opinion put forward by Suharsimi Arikunto (2010: 115). The population is the whole subject of research.the large that they wish to learn about is called a population (Gall, Gall \& Borg203: 163). From the three opinions it can be concluded that the population is all research subjects with the quality and characteristics that have been determined.

When viewed from the conclusions above, in this study the population was all training participants in strengthening principals with predetermined characteristics, namely the participants coming from Kebumen District, Central Java Province, amounting to 35 participants. The research location is in Kebumen, Central Java Province.

Sampling for this study was carried out by purposive sampling which is directly referring to the purpose of the implementation of the supervision module and the assessment of the performance of the education staff that is training for strengthening principals held by the district / city in collaboration with the Institute for Development and Empowerment of Principals / LPPKS. LPPKS is an institution under the Ministry of Education and Culture which has the authority to organize training for strengthening principals.

\section{Instruments and Data Collection Methods}

According to Moh. Nazir (2005: 221) that the data collection method is a systemic and standardized procedure to obtain the data needed. While Suharsimi Arikunto (2010: 137) states that in research activities how to obtain data known as the data collection method is how to obtain data known as the data collection method. Based on these two opinions it can be concluded that the method of data collection is a way to obtain data with systemic and standardized procedures.

The classification or division of data collection methods according to Moh. Nazir (2005: 212) there are 3 groups namely: direct observation methods, methods using questions, and special methods. Based on the data classification method in this study in collecting data the researcher took the observation method and the method of using questions. Moh. Nazir (2005: 212) further explained that the method of using questions can be done with interviews and questionnaires. Questionnaires rely on written information supplied directly by people in response to questions asked by the re (Denscombe, 2003: 144). According Suharsimi Arikunto (2010: 136) the questionnaire method is a list of questions given to others with the intention that people are willing to respond according to the user. Furthermore Suharsimi Arikunto (2010: 136-137) distinguishes questionnaires into 2 types when viewed from the way of giving responses, they are closed questionnaire and open questionnaire. Closed questionnaire is a questionnaire presented in such a way that the respondent only needs to give a check mark (v) or a cross $(\mathrm{x})$ in the appropriate column or place while the questionnaire is open where the respondent has the freedom to pour the desired response or answer. Based on this description, in this study researchers used a closed questionnaire and open questionnaire. To clarify and facilitate the preparation of the following instruments the instrument grids are presented as follows;

\section{a. Closed Questionnaire Instrument Lattice}

The aspects discussed in the closed questionnaire include; relevance (module content is related to the achievement of educational staff supervision competency standards and performance appraisal), adequacy (coverage involving the breadth and depth of module content, as well as the scope of the material), consistency, sequence of presentation (sequencing). 
From each of these aspects further indicators are determined for each of the aspects described as follows;

1. Relevance; (1) has a connection with the achievement of supervision planning sub competence that is able to plan supervision according to the needs of educational staff, (2) has a relationship with the achievement of sub-competence of supervision implementation that is able to conduct supervision for education staff by using appropriate supervision techniques, (3) related to the achievement of subcompetencies for follow-up supervision, which is able to follow up the results of supervision to the education staff. (4) has a relationship with the achievement of formative performance assessment sub competencies that is able to develop the performance standards of educational staff, (5) has a relationship with the achievement of sub competence in carrying out performance assessment that is able to carry out performance appraisal to educational staff.

2. Adequacy; (1) the breadth of the module content is sufficient to be applied in the field / school, (2) the depth of the module is sufficient to be applied in the field / school, (3) the scope or scope of learning material material types in the form of cognitive aspects (facts, concepts, principles, procedures), (4) the scope or scope of the module type of teaching material in the form of affective aspects, (5) the scope or scope of the module type of teaching material in the form of psychomotor aspects, (6) elaboration of the contents of the module into examples of the format of the supervision instrument so that it is easily applied in (7) elaboration of module contents into examples of performance assessment instrument formats so that they are easy to apply in the field.

3. Consistency; there is a difference between the contents of the module with the basic competencies and sub competencies that must be mastered by the training participants.

4. Sequencing; (1) procedural accuracy, namely procedural teaching material describing steps in sequence in accordance with the characteristics of learning materials (instructional materials that are prerequisite), (2) hierarchical accuracy of sequences, ie the module content depicts sequential sequences from the bottom up or down according to the order of supervision and performance appraisal sub competencies.

\section{b. Open Questionnaire Instrument Grilles}

The aspects discussed in the open questionnaire include; (1) Writing Systematics, (2) Appearance / Graphic Design, (3) Content / Content, (4) Suggestions. The instrument then compiles the instrument. In order to obtain the validity and reliability of the instrument, the instrument was tested on a training program for strengthening the school principal of Lamongan Regency, East Java Province on the 24th s.d. 30 September 2019 with 20 training participants as respondents.

\section{Data Analysis}

Quantitative data on a closed questionnaire were analyzed with mean analysis techniques. The average data analysis technique results from a closed questionnaire using the formula in the chart:

Closed Questionnaire Analysis Formula Chart

$$
\bar{X}=\frac{\sum X}{n}
$$

Information:

$\bar{X}=$ average value

$\mathrm{n}=$ number of evaluators

$\sum \mathrm{X}=$ total score of evaluator's answers 
The criteria for the average value of closed questionnaire data are listed in the following table:

Figure 2. Criteria Table The Average score of Closed Questionnaire Results

\begin{tabular}{|c|c|}
\hline Average & Criteria \\
\hline $4.20-5.00$ & Good \\
\hline $3.20-4.19$ & Good enough \\
\hline $2.20-3.19$ & Poor \\
\hline $1.00-2.19$ & Not Good \\
\hline
\end{tabular}

(Suharsimi Arikunto, 2004)

The results of the data obtained from open questionnaires are processed using qualitative descriptive processing by grouping similar responses and then generalizations are taken and then conclusions are made (Suharsimi Arikunto, 1999).

The results of data analysis from closed questionnaires and open questionnaires were used as a reference to determine the level of relevance of the supervision module and the assessment of the performance of the education staff with the needs of principals in the field.

\section{CHAPTER IV \\ DESCRIPTION OF RESEARCH RESULTS \\ Data and Discussion of Research Results}

Before the fieldwork was carried out, an instrument was developed in order to collect data as described above. In order to obtain the validity and reliability of the instrument, the instrument was tested on a training program for strengthening the school principal of Lamongan Regency, East Java Province on the 24th s.d. 30 September 2019 with the following results;

\section{Instrument Item Validity Analysis}

Figure 3. Instrument Item Validity Analysis Results Table

\begin{tabular}{|c|c|c|}
\hline Num. Item & Result Item & Validity \\
\hline 1 & 0,857 & Valid (r results $>0,468)$ \\
\hline 2 & 0,858 & Valid (r results $>0,468$ ) \\
\hline 3 & 0,844 & Valid (r results $>0,468$ ) \\
\hline 4 & 0,841 & Valid (r results $>0,468)$ \\
\hline 5 & 0,847 & Valid (r results $>0,468)$ \\
\hline 6 & 0,833 & Valid (r results $>0,468)$ \\
\hline 7 & 0,833 & Valid (r results $>0,468)$ \\
\hline 8 & 0,843 & Valid (r results $>0,468)$ \\
\hline 9 & 0,843 & Valid (r results $>0,468)$ \\
\hline 10 & 0,848 & Valid (r results $>0,468)$ \\
\hline 11 & 0,862 & Valid (r results $>0,468)$ \\
\hline 12 & 0,845 & Valid (r results $>0,468)$ \\
\hline 13 & 0,858 & Valid (r results $>0,468)$ \\
\hline 14 & 0,851 & Valid (r results $>0,468)$ \\
\hline 15 & 0,840 & Valid (r results $>0,468)$ \\
\hline
\end{tabular}

From the above data it can be seen that of the 15 items in the instrument, all items are included in the valid category when using the Critical Value Coefficient df: $18(\mathrm{~N}-2=20-2=18)$ with a significant level of $5 \%=0.468$. The instrument was declared reliable with alpha coefficients of 0.856. After that the instrument was used to retrieve data on the training of school principals in Kebumen Regency, Central Java Province, the results of which were discussed below.

Data and discussion obtained from the closed questionnaire are as follows; 


\section{Relevance}

Figure 4. Relevance Results Table

\begin{tabular}{|c|l|c|}
\hline Number & \multicolumn{1}{|c|}{ Indicator } & Score \\
\hline 1. & $\begin{array}{l}\text { Relation to the achievement of sub-competencies in the planning of } \\
\text { supervision of teaching staff }\end{array}$ & 3,83 \\
\hline 2. & $\begin{array}{l}\text { Relation to the achievement of sub-competencies in the } \\
\text { implementation of supervision of educational staff }\end{array}$ & 3,71 \\
\hline 3. & $\begin{array}{l}\text { Relation to the achievement of sub-competencies for follow-up } \\
\text { supervision of education staff }\end{array}$ & 3,80 \\
\hline 4. & $\begin{array}{l}\text { Relation to the achievement of sub-competencies in compiling } \\
\text { educational workforce performance standards }\end{array}$ & 3,71 \\
\hline 5. & $\begin{array}{l}\text { Relation to the achievement of sub-competencies carrying out } \\
\text { performance appraisals of educational staff }\end{array}$ & 18,65 \\
\hline \multicolumn{2}{|l}{ Total } & 3,73 \\
\hline
\end{tabular}

Based on the above data it can be explained that from the indicators on the aspect of the relevance of the highest score on the indicator of relevance to the achievement of subcompetency planning of education staff supervision and the lowest on the indicator of relevance to the achievement of sub-competence carry out an assessment of the performance of education staff. However, all indicators in the category are sufficient so that it can be concluded that the supervision module and the performance assessment of the teaching staff in the training of strengthening principals are declared to be quite relevant (Adapted from Arikunto, 2004).

\section{Adequacy}

Figure 5. Adequacy Results Table

\begin{tabular}{|c|l|c|}
\hline Number & \multicolumn{1}{|c|}{ Indicator } & Score \\
\hline 1. & The module content is sufficient to be applied in the field / school & 3,69 \\
\hline 2. & The module depth is sufficient to be applied in the field / school & 3,80 \\
\hline 3. & $\begin{array}{l}\text { The scope o of learning material types of material in the form of cognitive } \\
\text { aspects (facts, concepts, principles, procedures) }\end{array}$ & 3,54 \\
\hline 4. & $\begin{array}{l}\text { The scope of the module and type of teaching material in the form of } \\
\text { affective aspects }\end{array}$ & 3,60 \\
\hline 5. & $\begin{array}{l}\text { The scope of the module and type of teaching material in the form of } \\
\text { psychomotor aspects }\end{array}$ & 3,69 \\
\hline 6. & $\begin{array}{l}\text { Describing the contents of the module into examples of the instrument } \\
\text { supervision format so that it is easy to apply in the field }\end{array}$ & 3,57 \\
\hline 7. & $\begin{array}{l}\text { Explanation of module contents into examples of performance assessment } \\
\text { instrument formats so that they are easy to apply in the field 3.63 }\end{array}$ & 3,63 \\
\hline \multicolumn{2}{|l}{ Total } & 25,52 \\
\hline
\end{tabular}

Based on the above data it can be explained that from the indicators on the aspect of the adequacy of the highest score on the module depth indicator it is sufficient to be applied in the field / school and the lowest on the indicator Coverage or scope of learning material type of material in the form of cognitive aspects (facts, concepts, principles, procedure). However, all indicators in the category are sufficient so that it can be concluded that the supervision module and the performance appraisal of the teaching staff in training for strengthening principals are stated to have sufficient adequacy (Adapted from Arikunto, 2004). 


\section{Consistency}

Figure 6. Consistency Results Table

\begin{tabular}{|c|l|c|}
\hline Number. & \multicolumn{1}{|c|}{ Indicator } & Skor \\
\hline 1. & $\begin{array}{l}\text { There is a difference between the contents of the module with the basic } \\
\text { competencies and sub competencies that must be mastered by the } \\
\text { training participants. }\end{array}$ & 3,74 \\
\hline \multicolumn{2}{|c|}{ Total } & 3,74 \\
\hline \multicolumn{2}{|c|}{ Average } & 3,74 \\
\hline
\end{tabular}

Based on the above data, it can be explained at the same time it is concluded that the supervision module and performance appraisal of the education staff in the training of strengthening principals are stated to have a fairly good consistency value (Adapted from Arikunto, 2004).

\section{Sequence Section}

Figure 7. Sequence Section Results Table

\begin{tabular}{|c|l|c|}
\hline Number & \multicolumn{1}{|c|}{ Indicator } & Score \\
\hline 1. & $\begin{array}{l}\text { The accuracy of the procedural sequence that is teaching material } \\
\text { procedurally describes the steps in sequence in accordance with the } \\
\text { characteristics of learning materials (teaching materials that are } \\
\text { prerequisite / prerequisite). }\end{array}$ & 3,83 \\
\hline 2. & $\begin{array}{l}\text { The hierarchical accuracy of the sequence, namely the contents of the } \\
\text { module illustrates a sequence that is tiered from the bottom up or from } \\
\text { top to bottom in accordance with the order of sub competencies, } \\
\text { supervision and performance appraisal. }\end{array}$ & 3,89 \\
\hline \multicolumn{2}{|l}{ Total } & 7,71 \\
\hline
\end{tabular}

Based on the above data it can be explained that from the indicators on the aspect of the highest score sequencing on the procedural accuracy sequence indicators ie teaching material procedurally describes the steps in sequence according to the characteristics of the learning material (teaching materials that are prerequisite / prerequisite) and the lowest on hierarchical accuracy of sequence indicators that is the contents of the module describes a sequence that is tiered from the bottom up or from top to bottom in accordance with the order of sub competence supervision and performance appraisal. However, the two indicators in the category are sufficient so that it can be concluded that the supervision module and the performance appraisal of the teaching staff in training for strengthening principals are stated to have a fairly good level of sequencing (Adapted from Arikunto, 2004).

Based on the data of each of these aspects can then be summarized in the table below;

Figure 7. All of Aspect Results Table

\begin{tabular}{|c|l|c|}
\hline Number & Aspect & Score \\
\hline 1. & Relevance & 3,74 \\
\hline 2. & Adequacy & 3,64 \\
\hline 3. & Consistency & 3,74 \\
\hline 4. & Sequiensi & 3,86 \\
\hline \multicolumn{2}{|c|}{ Total } & 14,98 \\
\hline \multicolumn{2}{|c|}{ Average } & 3,74 \\
\hline
\end{tabular}


From this data can be described in graphical form as follows:

Figure 8. Graph of All Aspect

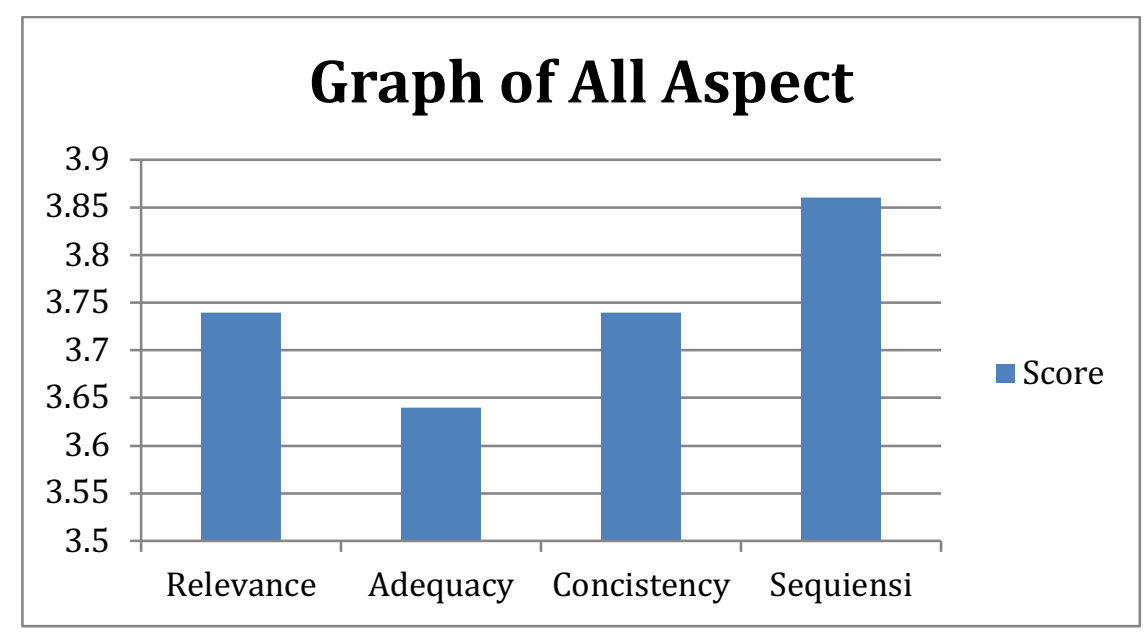

From the results of data processing, it was found that the mean index was 3.74 in the quite good category (Adapted from Arikunto, 2004). Thus it can be concluded that the supervision module and performance assessment of the teaching staff in strengthening principals training are good enough to be used in training for strengthening principals because they are quite relevant, have enough content, are quite consistent and are quite sequential among materials.

Data and discussion obtained from the open questionnaire are as follows;

Figure 9. Data and discussion obtained from the open questionnaire Results Table
\begin{tabular}{|l|l|l|r|}
\hline No. & \multicolumn{1}{|c|}{ Focus } & \multicolumn{1}{|c}{ Statement Categories } & $\%$ \\
\hline 1 & \multirow{2}{*}{ Writing system } & A. Very systematic & 3,13 \\
\cline { 3 - 4 } & & B. Quite systematic & 77,10 \\
\cline { 3 - 4 } & & C. Not systematic yet & 8,57 \\
\hline 2 & \multirow{2}{*}{ Appearance / } & A. Very good & 17,15 \\
\cline { 3 - 4 } & Graphic Design & B. Pretty Good & 74,23 \\
\cline { 3 - 4 } & & C. Less good & 8,57 \\
\hline 3 & \multirow{2}{*}{ Content } & A. Complete and very detailed & 10.00 \\
\cline { 3 - 4 } & & B. Quite Complete and detailed & 78,58 \\
\cline { 3 - 4 } & & C. Not complete and detailed & 11,42 \\
\hline 4 & \multirow{2}{*}{ Suggestions } & The description of the material needs additional \\
\cline { 3 - 4 } & & Sentences are made more operational \\
\cline { 3 - 4 } & & Examples of performance appraisal of educational staff to be completed \\
\cline { 3 - 4 } & & There is no suggestion \\
\hline
\end{tabular}

Based on the table above it can be explained that in the systematic aspect of writing the category of statement "quite systematic" has the largest percentage of $77.10 \%$, in the aspect of appearance / graphic design the category of statement "quite good" has the largest percentage of 74.23\%, in the aspect of content / content category statement "quite complete and detailed" has the largest percentage of 78.58\%. Thus the supervision and assessment modules of the teaching workforce can be said to be quite systematic, good appearance, quite complete, and quite detailed. The suggestions have been grouped into four things namely; sentences are made more operational, examples of performance appraisal of education personnel are to be completed, elaboration of material needs to be added, and there are some who provide advice. 


\section{CHAPTER V \\ CONCLUSIONCONCLUSIONS}

Based on the data in the previous chapter, it can be concluded that the supervision module and the performance assessment of the teaching staff have a fairly good level of relevance, adequacy, consistency, and sequence. This is contained in the results of quantitative data processing with an average index of 3.74 in the quite good category (Adapted from Suharsimi Arikunto, 2004) and qualitatively concluded that the module is quite systematic, good appearance, quite complete and detailed. However, it is necessary to develop further modules, especially those relating to suggestions such as; the need for more complete examples of educational staff, performance assessment formats, the need for more detailed explanations, and the understandable explanation to make operational ones are not too normative. If this suggestion will be done so that the module will be in the excellent category andt it will be more appropriate to be used in the training of strengthening principals.

\section{Suggestions}

Even though the category has been quite good but further development of the supervision module and assessment of the performance of the teaching staff is still needed to be more perfect. The module is easy to be understood when it is used in strengthening training of principals and can be easily applied by the principals in carrying out supervision and assessing the performance of the educational staff.

\section{References}

Anwar Ilham. (2010). Pengembangan Bahan Ajar Bahan Kuliah Online. Bandung : Direktori. Universitas Pendidikan Indonesia

Descombe, martyn.(2003). The Good research Guide: For small-scale social research guide. Maidenhead.Philadelpia: Open University Press.

Gall,Meredith D, Gall Joyce P \& Borg Walter R. (2003). Educational Reasearch: An Introduction. USA: Pearson Education.Inc.

Kemdiknas. (2008). Penilaian Kinerja Kepala Sekolah. Direktorat Tenaga Kependidikan Direktor Jenderal Peningkatan Mutu dan Tenaga Kependidikan Jakarta: Depdiknas

Kemdikbud. (2017). Panduan Kerja Kepala Sekolah. Jakarta : Direktorat Jenderal Guru dan Tenaga Kependidikan Kemdikbud. (2018). Peraturan Menteri Pendidikan dan Kebudayaan Nomor 6 Tahun 2018 Tentang Penugasan Guru Sebagai Kepala Sekolah. Jakarta : Kemdikbud

Kemdikbud. (2018). Peraturan Direktur Jendral Guru dan Tenaga Kependidikan Tentang Petunjuk Teknis Penugasan Guru Sebagai kepala Sekolah. Jakarta : Kemdikbud

Kemdiknas. (2007). Peraturan Menteri Pendidikan Nasional Nomor 13 Tahun 2007 Tentang Standar Kepala Sekolah. Jakarta : Kemdiknas

Kemenkumham. (2017). Peraturan Pemerintah Republik Indonesia Nomor 17 Tahun 2017 Tentang Guru. Jakarta : Kemenkumham

Lembaga Administrasi Negara. (2009). Diklat Sebagai Suatu Sistem. Jakarta : Lembaga Administrasi Negara Moh. Nazir. (2005). Metode Penelitian. Jakarta : Ghalia Indonesia.

Neagley,Pross L and Evans N. Dean (1980). Handbook for Effective Supervision of Instruction. Englewood Cliffs: Prentice-Hall,Inc.

Oliva Peter F. (1984). Supervision for Today's Schools. New York: Longman.

Sekretaris Negara. (2000). Peraturan Pemerintah Republik Indonesia Nomor 101 Tahun 2000 Tentang Pendidikan dan Pelatihan Pegawai Negeri Sipil. Jakarta : Sekretaris Negara

Sekretaris Negara. (2003). Undang-Undang Republik Indonesia Nomor 20 Tahun 2003 Tentang Sistem Pendidikan Nasional. Jakarta : Sekretaris Negara 
Sergiovanni, Thomas J. and Starratt, Robert J. (1979). Supervision: Human Perspectives. New York: McGraw-Hill Book Company.

Suharsimi Arikunto. (2010). Prosedur Penelitian Suatu Pendekatan Praktis. Jakarta : Rineka Cipta

Suharsimi Arikunto. et.all. (2004). Evaluasi Program. Jakarta : Bumi Aksara

Suharsimi Arikunto. (2004). Penilaian Program Pendidikan. Jakarta: Rineka Cipta Jakarta

Suharsimi Arikunto. (2004). Dasar-Dasar Supervisi. Rineka Cipta, Jakarta

Winkel. (2009). Psikologi Pengajaran. Yogyakarta : Media Abadi 